ISSN 1991-8631

\title{
Quality of fermented cassava flour processed into placali
}

\author{
Casimir Anauma KOKO ${ }^{1 *}$, Ahou KONAN ${ }^{1}$, Fabrice TÉTCHI ${ }^{2}$, Emmanuel ASSIDJO ${ }^{1}$ \\ and Georges AMANI ${ }^{2}$ \\ ${ }^{1}$ Laboratoire des Procédés Industriels, de Synthèse et Environnement, \\ Institut National Polytechnique Houphouët-Boigny, BP 1313 Yamoussoukro, Côte d'Ivoire. \\ ${ }^{2}$ Laboratoire de Biochimie Alimentaire et de Technologie des Produits Tropicaux, UFR/STA, \\ Université d'Abobo-Adjamé, 02 BP 801 Abidjan 02, Côte d'Ivoire. \\ *Corresponding author, E-mail: anaumako@yahoo.fr; Tel: (225) 073640 95; Fax: 30646660
}

\begin{abstract}
Fermented cassava flour was obtained from Yace variety. Cassava roots were washed, peeled and ground. After adding cassava inoculums at $8 \%(\mathrm{~m} / \mathrm{m})$, the pulp was allowed to ferment for 72 hours at ambient temperature. The fermented dough was removed, squeezed and oven-dried for 48 hours at $55{ }^{\circ} \mathrm{C}$. The dried product was ground and sieved with a $200 \mu \mathrm{m}$ mesh sieve. Proximate composition and the ability of fermented flour to be processed into placali appreciated by consumers were evaluated. Moisture, protein, ash, fat, total sugars and cyanide contents were low while starch, total carbohydrate and energy contents were high. Minerals like phosphorus, calcium, magnesium, iron and zinc were available and well-balanced. The sensory evaluation test indicated a significant difference $(\mathrm{P}<0.05)$ between the different placali samples in terms of visual appearance, odour, taste, texture and global appreciation. It is a clear indication that reconstitution proportion affects all the hedonic appreciations evaluated. Placali prepared from fermented cassava flour were then highly appreciated when reconstitution proportion (flour to water ratio) was within 1:3.5 and 1:3.
\end{abstract}

(c) 2012 International Formulae Group. All rights reserved.

Keywords: Proximate composition, cooking time, sensory analysis, reconstituted dough.

\section{INTRODUCTION}

Cassava (Manihot esculenta, Crantz) is an important staple food crop for millions of people in the tropical areas of the world. Cassava roots are an important source of energy and contain mainly carbohydrates, of which $80 \%$ is starch (Koko et al., 2010). Traditionally, cassava roots are processed by several methods, which vary widely from region to region into products such as gari, fufu, lafun, flour, chips, starch, syrups, dextrins, and alcohol (Nwabueze and Odunsi, 2007). Placali is one of the most important cassava products in West Africa. It is a fermented and gelatinized cassava product. It is known by different names in different countries. In Ivory Coast, placali is commonly consumed and is the second well known cassava product after Attieke (Koffi-Nevry et al., 2007). Its preparation needs meaningful 
unit operations which constitute a tiresome job for housewives. That leads to a product with variable quality. It is therefore necessary, to produce flour that can be reconstituted very easily into placali. Work on cassava reconstituted dough has been reported and concerned products like fufu, lafun (Tanya et al., 2006; Etudaiye et al., 2009). Production of placali of acceptable properties using fermented cassava flour, has not adequately reported in literature. Aboua (1992) has mentioned the feasibility of this process. But, it is not known to what extent this reconstituted dough can be accepted by consumers.

The objective of this research was to produce and evaluate fermented cassava flour in terms of its proximate composition. This study took place also to provide information on the dough reconstitution process and the acceptance of such byproduct by consumers. It is expected that the result obtained from the study will contribute in valorizing the instant placali flour and also serve as a guide for future research.

\section{MATERIALS AND METHODS} Source of raw materials

Fresh roots of one local cassava variety (Yace) were used in this study. These roots were from a farm near Yamoussoukro (centre of Ivory Coast).

\section{Production of fermented cassava flour}

Fresh roots were peeled, washed with a knife and cut into large longitudinal pieces. These pieces were ground and a cassava inoculum was added at $8 \%$ dough (Koko et al., 2010). The mass was packed into bags and let for three days at ambient temperature (28$\left.30{ }^{\circ} \mathrm{C}\right)$ without any compression. The fermented dough was then removed and squeezed. When the dough was sufficiently pressed, it was oven-dried for 48 hours at 55 ${ }^{\circ} \mathrm{C}$. The dried product was ground and sieved with a $200 \mu \mathrm{m}$ mesh sieve to obtain the fermented cassava flour.

\section{Physicochemical analyses}

Moisture, ash, starch, protein and fat contents were determined using BIPEA (1976) method. Total acidity and $\mathrm{pH}$ were obtained using method described by Dufour et al. (1996). The cyanide content was determined by FAO method (1956). Total sugars and total carbohydrate contents were quantified respectively by methods of Dubois et al. (1956) and Bertrand (1913). Atwater and Rosa (1899) coefficients were used to calculate caloric energy. Minerals such as calcium, magnesium, zinc and iron were quantified by Atomic Absorption Spectrometer and phosphorus by Spectrophotometer after samples digestion using IITA method (1981).

\section{Placali samples preparation}

Many trials were made to obtain placali preparation conditions (flour to water ratio, quantity of water, cooking time). After this, four placali samples were prepared by adding a fixed quantity of fermented cassava flour $(50 \mathrm{~g})$ in a variable quantity of boiled water. Cooking time was also fixed at 12 minutes for all the placali samples. The proportion of reconstitution was then:

- for sample F50: 1 part of flour in 2 parts of water $(1: 2)$

- for sample F33: $(1: 3)$

- for sample F28: $(1: 3.5)$

- For sample F25: (1:4).

The placali samples obtained were disposed on plates for sensory analysis.

\section{Sensory analysis}

A panel of 60 non-trained persons was selected to evaluate the acceptance of placali samples prepared from fermented cassava flour. These persons were selected between regular consumers of such product. The different samples (F50, F33, F28 and F25) 
were evaluated for their taste, odour, texture, global appreciation and visual appearance. The evaluation was based on 9-hedonic scale (Harry and Hildegarde, 2010).

\section{Statistical analysis}

Data obtained from the sensory analysis of placali samples were subjected to statistical analysis using STATISTICA 8.0 software package. Analysis of variance (ANOVA) was done. Means separation using Tukey HSD multiple comparison tests was done to determine significant differences at $5 \%$ probability between placali samples.

\section{RESULTS}

The proximate composition of fermented cassava flour produced from Yace cultivar is shown in Table 1. There was low moisture content in fermented flours. It was also observed that several other parameters have low contents. It is the case of protein, fat, ash, total sugars and cyanide contents. As compared to these parameters, carbohydrate content was much high. In addition the main constituent of these carbohydrates was starch.
As shown in Table 1, the result of energy content showed that fermented cassava flour was an important source of calories. The fermented flour processed was acid. Fermented flour contained also minerals like phosphorus, magnesium, iron, zinc, calcium (Table 2). The zinc content was the lowest one, while phosphorus seemed to be the highest.

Processing of fermented cassava flour into placali showed ease of reconstitution. Four placali samples were prepared from fermented cassava flour produced and submitted to sensory evaluation by consumers. The results are shown in Table 3.

The sensory evaluation test indicated a significant difference $(\mathrm{P}<0.05)$ between the different placali samples in terms of visual appearance, odour, taste, texture and global appreciation. Sample F28 was highly appreciated for its visual appearance, odour, taste, texture and global appreciation. Placali sample F50 was the least appreciated for the same parameters. Difference of appreciation between sample F28 and sample F33 was only on the taste.

Table 1: Proximate composition (on dry weight basis) of fermented cassava flour produced from Yace variety in Yamoussoukro.

\begin{tabular}{lc}
\hline Composition & Contents \\
\hline Moisture $(\%)^{*}$ & $10.49 \pm 0.65$ \\
Protein $(\%)$ & $1.31 \pm 0.09$ \\
$\mathrm{pH}$ & $4.00 \pm 0.05$ \\
Total acidity $(\mathrm{meq} / 100 \mathrm{~g})$ & $14.94 \pm 0.75$ \\
Fat $(\%)$ & $0.51 \pm 0.06$ \\
Ash $(\%)$ & $1.15 \pm 0.05$ \\
Total sugars $(\%)$ & $1.43 \pm 0.05$ \\
Cyanide $(\mathrm{mg} / \mathrm{kg}) *$ & $10.00 \pm 0.66$ \\
Starch $(\%)$ & $83.16 \pm 1.95$ \\
Carbohydrate $(\%)$ & $93.67 \pm 1.00$ \\
Energy (kcal/100 g) & $384.53 \pm 4.7$ \\
\hline Tabulated values are means \pm SD of triplicate analysis. \\
(*) Expressed on fresh matter
\end{tabular}


Table 2: Mineral contents (on dry weight basis) of fermented cassava flour produced.

\begin{tabular}{lc}
\hline Minerals & Contents \\
\hline Phosphorus $(\mathrm{mg} / 100 \mathrm{~g})$ & $86.00 \pm 4.58$ \\
Magnesium $(\mathrm{mg} / 100 \mathrm{~g})$ & $66.66 \pm 1.15$ \\
Iron $(\mathrm{mg} / 100 \mathrm{~g})$ & $3.78 \pm 0.15$ \\
Zinc $(\mathrm{mg} / 100 \mathrm{~g})$ & $1.68 \pm 0.17$ \\
Calcium $(\mathrm{mg} / 100 \mathrm{~g})$ & $62.66 \pm 3.05$ \\
Calcium/Phosphorus & $0.72 \pm 0.04$ \\
\hline Tabulated values are means \pm SD of triplicate analysis. &
\end{tabular}

Table 3: Hedonic appreciation notes of placali prepared from fermented cassava flour.

\begin{tabular}{|c|c|c|c|c|c|}
\hline \multirow[b]{2}{*}{$\begin{array}{l}\text { Placali } \\
\text { samples }\end{array}$} & \multicolumn{5}{|c|}{ Hedonic appreciation notes } \\
\hline & Taste & Odour & Texture & Visual appearance & $\begin{array}{c}\text { Global } \\
\text { appreciation }\end{array}$ \\
\hline F50 & $4.73 \pm 1.92^{\mathrm{a}}$ & $4.73 \pm 1.95^{\mathrm{a}}$ & $3.2 \pm 1.65^{\mathrm{a}}$ & $3.53 \pm 1.89^{\mathrm{a}}$ & $3.68 \pm 1.3^{\mathrm{a}}$ \\
\hline F33 & $5.85 \pm 1.86^{\mathrm{b}}$ & $5.76 \pm 1.45^{\mathrm{b}}$ & $6.21 \pm 1.54^{\mathrm{b}}$ & $5.9 \pm 1.44^{\mathrm{b}}$ & $6.23 \pm 1.59^{b}$ \\
\hline F28 & $6.83 \pm 1.5^{\mathrm{c}}$ & $6.4 \pm 1.67^{\mathrm{b}}$ & $6.66 \pm 1.78^{b}$ & $6.3 \pm 1.83^{b}$ & $6.68 \pm 1.58^{\mathrm{b}}$ \\
\hline $\mathrm{F} 25$ & $5.97 \pm 1.97^{\mathrm{b}}$ & $5.9 \pm 1.73^{\mathrm{b}}$ & $5.23 \pm 2.48^{\mathrm{c}}$ & $5.71 \pm 1.86^{\mathrm{b}}$ & $5.41 \pm 2.08^{\mathrm{c}}$ \\
\hline
\end{tabular}

Tabulated values are means \pm SD of sixty determinations. The values with different letters in each column are significantly different $(\mathrm{P}<0.05)$.

\section{DISCUSSION}

The moisture content recommended in the edible cassava flour is less than $13 \%$ (Sanni et al., 2005). In the present study, value of moisture content of fermented flour was within the recommended standard. The low moisture content of fermented cassava flour is an indication of a good stable shelf life if packaged and stored. The acid $\mathrm{pH}$ of fermented flour could prevent from pathogenic microorganisms multiplication (Koffi-Nevry et al., 2008; Toka et al., 2008). Low $\mathrm{pH}$ values, associated to low moisture content contribute to increase the stability and therefore the shelf life of fermented cassava flour.

Ash and cyanide contents were also low. Fortunately, values of ash and cyanide contents were less than the maximum Codex standard for edible cassava flour (3.0\% and 10 $\mathrm{mg} / \mathrm{kg}$ respectively) (Codex Alimentarius, 1991). The low protein content of flour is not a serious issue as reconstituted dough is usually consumed accompanied with sauce that contained protein (Etudaiye et al., 2009). Indeed, placali is always consumed with sauce included generally both sources of protein (animal and vegetable). Fermented cassava flour is an energizing food due certainly to its high carbohydrate content. It is well-known that cassava flour is normally rich in carbohydrate with starch as main constituent (Koko et al., 2010). Oyewole and Afolami (2001) determined the starch content of cassava flour to be 77 to $78 \%$. In the present study, the value of starch was much higher. It is certainly due to the influence of cultivar (Koko et al., 2010). Fermented flour 
contains also minerals. These are available due to fermentation unit according to Yao et al. (2009). In addition, some of these minerals are well-balanced. It is the case of calcium and phosphorus whose ratio was close to the optimal absorption value of 0.70 (Javillier et al., 1967). These results confirm earlier report that cassava has been recognized as a suitable crop for micronutrient intervention in Africa (Oyewole and Asagbara, 2003).

Placali prepared from fermented cassava flour was diversely appreciated. Sample F28 was highly appreciated for its visual appearance, odour, taste, texture and global appreciation. Placali sample F50 was the least appreciated for the above parameters. It is a clear indication that reconstitution proportion affects all the hedonic appreciations evaluated. The texture of fermented dough is one of the main parameters that guide consumer choice (Oduro-Yeboah et al., 2007). In this study, sample F28 and sample F33 have the most appreciated texture. Then, these placali samples which differed only on the taste were the most appreciated ones. Consumers prefer sample F28 and sample F33 as placali with desired characteristics according to their food habits. Therefore, placali prepared from fermented cassava flour were highly appreciated when reconstitution proportion (flour to water ratio) was within 1:3.5 and 1:3.

\section{Conclusion}

The present study has clearly shown the physicochemical characteristics of fermented cassava flour processed. Its proximate composition showed low $\mathrm{pH}$ value, low moisture and cyanide contents, and high carbohydrate and starch contents. These are indication of stable shelf life and non toxicity. Fermented cassava flour is an available source of calories and minerals to consumers. Fermented flour was processed easily and successfully into placali highly appreciated by consumers. A reconstitution proportion has been identified by consumers to provide placali with desirable qualities. In Ivory
Coast, rapid urban growth and development place a dynamic challenge to fermented cassava flour produced. This kind of process has the potential to help developing countries diversify their manufacturing base, improve their food security and generate more income.

\section{REFERENCES}

Aboua F. 1992. Chemical changes in cassava tubers (Manihot esculenta Crantz), during production of placali. Trop. Sci., 32: 353-360.

Atwater W, Rosa E. 1899. A new respiratory calorimeter and the conservation of energy in human body. Physical. Rev., 9: $214-251$.

Bertrand G. 1913. Dosage de sucres. In Guide pour les Manipulations de Chimie Biologie, Dunod et Pinat (Eds) : Paris; 20.

Codex Alimentarius. 1991. Norme Codex pour la Farine Comestible de Manioc (Norme régionale africaine), CODEX STAN 176-1991. FAO: Rome.

Dubois M, Gilles A, Hamilton JJ, Rebers PA and Smith F. 1956. Colorimetric method for determination of sugars and related substances. Anal. Chem., 28: 350-356.

Dufour D, Larsonneur S, Alarçon F, Brabet C, Chuzel G. 1996. Improving the bread making potential of cassava sour starch. In Cassava Flour and Starch: Progress in Research and Development, Dufour D, O'Brien GM, Best R (Eds). CIAT: Cali; 133-142.

Etudaiye H, Nwabueze TU, Sanni LO. 2009. Quality of fufu processed from cassava mosaic desease (CMD) resistant varieties. African Journal of Food Science, 3(3): 61-67.

FAO. 1956. Acide cyanhydrique. Dosage par la méthode alcaline de titrage du manioc. In Traitement $d u$ Manioc. Food and Agriculture Organization of United Nations: Rome; 84-85.

Harry TL, Hildegarde H. 2010. Sensory Evaluation of Food: Principles and 
Practices $\left(2^{\text {nd }}\right.$ edn). Springer: New York.

IITA. 1981. Analyses des Prélèvements Pédologiques et Végétaux. Manuel $\mathrm{N}^{\circ}$ 1. IITA : Ibadan.

Javillier M, Polonovski M, Florki N, Boulanger P, Lemoigne M, Roche J, Wurmser R. 1967. Traité de Biochimie Générale. Masson: Paris.

Koffi-Nevry R, Koussémon M, Aboua F. 2007. Chemical and organoleptic properties of attoukpou made from two cassava varieties (Manihot esculenta Crantz), Bonoua and IAC, J. Food Technol., 54(4): 300-304.

Koffi-Nevry R, Koussemon M, Nanga YZ, Abro MM, Kakou $\mathrm{C}$ and Kablan $\mathrm{T}$. 2008. Evolution de la microflore et caractéristiques physico-chimiques d'un aliment traditionnel à base de manioc (Manihot esculenta Crantz) fermenté: Le Bêdêcouman. Europ. J. Sci. Res., 21: 259-267.

Koko AC, Assidjo NE, Amani G. 2010. Cultivars and sampling regions influence on cassava roots and their fermented flours characteristics. $J$. Appl. Sci. Res., 6(12): 2219-2229.

Nwabueze TU, Odunsi FO. 2007. Optimization of process conditions for cassava (Manihot esculenta) lafun production. Afr. J. Biotechnol., 6(5): 603-611.

Oduro-Yeboah C, Jonhson T, Sakyi-Dawson OE. 2007. Caractérisation du profil sensoriel des propriétés de la texture du Foufou à base de farines de maniocbanane plantain. In Atelier International sur les Potentialités à la Transformation du Manioc en Afrique de l'Ouest, Amani G, Nindjin C, N'zué B, Tschannen A, Aka D (Eds). FID Afrique: Abidjan; 183-186.

Oyewole OB and Afolami OA. 2001. Quality and preference of different cassava varieties for "Lafun" production. $J$. Food Tec. Afr., 6: 27-29.

Oyewole OB, Asagbara Y. 2003. Improving traditional Cassava processing for nutritional enhancement. Food Nutr. Agric., 32: 17-21.

Sanni LO, MaziyaDixon B, Akanya CI, Alaya Y, Egwuonwu CV, Okechukwu RU, Ezedinma C, Akoroda M, Lemchi J, Ogbe F, Okoro E, Tarawali G, Mkumbira J, Patino M, Semakula G, Dixon A. 2005. Standard for Cassava Products and Guidelines for Export. IITA: Ibadan.

Tanya AN, Djoulde RD, Ejoh AR, Mbahe R, Hamidou H. 2009. Physicochemical and Sensory Analysis of Fermented Flour "Kumkum" from Three Improved and One Local Cassava Varieties in the Adamawa Province of Cameroon. Pakistan Journal of Nutrition, 5(4): 355-358.

Toka MD, Djéni NT, Djè KM. 2008. Improved process of cassava processing into "Attiéké", a traditional food product of Côte d'Ivoire. Int. J. Food Eng., 4(5): 10.

Yao AA, Egounlety M, Kouamé LP, Thonart P. 2009. Les bactéries lactiques dans les aliments ou boissons amylacés et fermentés de l'Afrique de l'Ouest : leur utilisation actuelle. Annales de Médecine Vétérinaire, 153: 54-65. 